\title{
Identifikasi Makroinvertebrata Permukiman sebagai Aktivitas Belajar Daring di Era Pandemi Covid-19
}

\author{
Syarif Hidayat Amrullah"1, St. Aisyah Sijid², Zulkarnain ${ }^{3}$ \\ 1,2,3) UIN Alauddin Makassar, syarifhidayat.amrullah@uin-alauddin.ac.id
}

\begin{abstract}
ABSTRAK
Salah satu habitat terrestrial bagi hewan makroinvertebrata adalah area permukiman. Penelitian ini bertujuan untuk mengetahui jenis hewan makroinvertebrata yang terdapat pada satu area permukiman. Hasil identifikasi digunakan untuk memberikan gambaran tentang pengamatan langsung makroinvertebrata di permukiman yang dapat mendukung aktivitas pembelajaran daring di tengah pandemi Covid-19. Identifikasi makroinvertebrata dilakukan secara langsung dengan pedoman identifikasi lapangan dan dilanjutkan di Laboratorium Biologi FST UIN Alauddin Makassar. Lokasi pengambilan sampel ditentukan pada lima titik lahan yang dimiliki warga. Setiap titik dibuat quadrant transect berukuran $50 \mathrm{~m}$ x $50 \mathrm{~m}$ berpusat pada tengah lahan tersebut, dengan $25 \mathrm{~m}$ masing-masing ke setiap arah mata angin. Pengambilan sampel dilakukan dengan hand-shorting dan sweep net. Adapun pengukuran variabel faktor lingkungan meliputi: suhu, intensitas cahaya, dan kelembaban, dilakukan dua kali sehari. Respon mahasiswa terhadap pengamatan di permukiman diketahui melalui pengisian Google Form. Data dianalisis secara deskriptif dan dilaporkan dalam bentuk tabel dan gambar. Hasilnya, ditemukan 23 jenis makroinvertebrata dalam 17 ordo, 5 kelas, dan 3 filum. Sebanyak $57 \%$ mahasiswa mengalami peningkatan pemahaman dengan aktivitas pengamatan langsung makroinvertebrata permukiman. Namun demikian, kegiatan tersebut dinilai belum cukup untuk mengakomodir pemahaman mahasiswa secara keseluruhan, dengan 64\% mahasiswa masih merasa belum cukup memahami tentang invertebrata dan $87 \%$ mahasiswa menganggap pelaksanaan praktikum lapangan masih perlu untuk dilakukan.
\end{abstract}

Kata kunci: identifikasi, makroinvertebrata, permukiman, aktivitas

\begin{abstract}
One of the terrestrial habitats for macroinvertebrates is a residential area. This study aims to determine the types of macroinvertebrates found in a residential area. The identification results are used to provide an overview of how direct observation of macroinvertebrates in residential support the online learning activity in the Covid-19 pandemic era. Identification of macroinvertebrates was carried out directly with field identification guide and continued at the Biology Laboratory of FST UIN Alauddin Makassar. Sampling locations were determined at five points of land owned by residents. Each point is made a quadrant transect measuring $50 \times 50 \mathrm{~m}$ centered in the middle of the land, with $25 \mathrm{~m}$ each in every cardinal direction. Sampling by hand-
\end{abstract}


shorting and sweep net. Measurement of environmental factors, including temperature, light intensity, and humidity, was carried out twice a day. Student responses are known through filling out the electronic form (Google Form). The data obtained were analyzed descriptively and reported as tables and figures. Result shown 23 types of macroinvertebrates were found which were grouped into 17 orders, 5 classes, and 3 phyla. As many as 57\% of students experienced an increase in understanding by direct observation of residential macroinvertebrates. However, these activities were not deemed sufficient to accommodate students' overall understanding, with $64 \%$ of students still feeling that they did not understand enough about invertebrates and $87 \%$ of students considering the implementation of field practicums still necessary.

Keywords: identification, macroinvertebrate, residential, activity

\section{PENDAHULUAN}

Invertebrata merupakan kelompok hewan yang tidak dilengkapi dengan columna vertebralis yang menjadi ciri utama pada kelompok vertebrata. Kelompok hewan ini dapat bertindak sebagai penyedia lingkungan yang sehat, mulai dari ekosistem terumbu karang yang berwarna-warni di lautan, dan menyediakan berbagai jenis makanan yang tak terhingga jumlahnya bagi hewan-hewan lain di muka bumi (Kotpal, 2013). Makroinvertebrata menurut Davis dan Christidis (1997) dalam Komarawidjaja, (2011) digolongkan ke dalam tujuh kelompok, yaitu Platyhelminthes, Nemathelminthes, Annelida, Mollusca, Arachnida, Crustacea, dan Insecta. Ukuran tubuh makroinvertebrata sebagai salah satu bagian dari makrofauna yang dijelaskan dalam Hanafiah et al., (2013) berkisar antara $2-20 \mathrm{~mm}$, terdiri dari herbivora (pemakan tanaman) dan karnivora (pemakan hewan kecil). Kehidupan makroinvertebrata memiliki cakupan yang sangat luas. Kelompok hewan ini dapat hidup pada habitat laut, estuaria dan lahan basah di pesisir, habitat air tawar, juga habitat terrestrial. Kemampuan berasosiasi dengan organisme lain, termasuk dengan tumbuhan dan hewan, membuat hewan ini dapat bertahan hampir di semua tipe lingkungan. Asosiasi ini lebih dikenal dengan istilah simbiosis, dapat dibagi menjadi parasistisme (pada beberapa kelompok cacing), parasitoid (pada beberapa insekta), dan menjadi pathogen pada manusia yang lebih dikenal dengan zoonosis; mutualisme (pada beberapa pollinator, scavenger, dan dekomposer); juga komensalisme (Brusca et al., 2016).

Salah satu habitat terestrial bagi hewan makroinvertebrata adalah area permukiman. Definisi permukiman menurut UU No. 1 tahun 2011 pasal 1 adalah bagian dari lingkungan hunian yang terdiri dari atas lebih dari satu satuan perumahan. Hunian tersebut mempunyai sarana, prasarana, utilitas umum, serta mempunyai 
penunjang kegiatan fungsi lain, baik di kawasan perkotaan ataupun kawasan pedesaan. Kawasan permukiman adalah bagian dari kawasan budidaya yang ditetapkan dalam rencana tata ruang dengan fungsi utama untuk permukiman (Kristiani et al., 2015). Hewan makroinvertebrata di permukiman umumnya dianggap sebagai bioindikator. Misal, keberadaan kecoa sebagai hama pada rumah tangga menjadi indikator kurangnya menjaga kebersihan (Meilin \& Nasamsir, 2016). Begitupun dengan keberadaan capung di atas sumber air, baik alami maupun buatan, menjadi pertanda kualitas air yang masih baik dan layak untuk dikonsumsi, sehingga dapat dianggap stabilitas ekosistem perairannya masih tinggi (Amrullah, 2018).

Pandemi Covid-19 menjadi tantangan baru bagi dunia pendidikan untuk menginovasi jalannya pembelajaran. Jurusan eksakta di perguruan tinggi, seperti Jurusan Biologi menjadi lebih rumit, karena tak hanya kegiatan perkuliahan yang berlangsung dari rumah, melainkan juga kegiatan praktikum. Bahkan kegiatan rutin semacam praktikum lapangan terpaksa ditiadakan. Aktivitas pembelajaran secara daring sebagai bentuk antisipasi penyebaran wabah Covid-19 memberikan gambaran bahwa mahasiswa memiliki fasilitas-fasilitas pendukung pembelajarannya. Pembelajaran daring juga sangat fleksibel dalam pelaksanaannya, sehingga dapat memotivasi peserta didik untuk lebih aktif. Selain itu juga dapat meminimalisir keramaian dan mendorong perilaku social distancing, sehingga sangat efektif menekan penyebaran wabah Covid19. Nilai positif selain kemandirian belajar adalah juga dapat meningkatkan minat dan motivasi, meningkatkan keberanian mengemukakan pertanyaan ataupun gagasan. Namun dibalik itu juga ada beberapa kendala yang menjadi nilai minusnya, antara lain lemahnya pengawasan terhadap aktivitas mahasiswa saat pembelajaran berlangsung, kurangnya sinyal untuk suplai jaringan terutama bagi yang tinggal di pelosok, juga mahalnya biaya pembelian kuota (Sadikin \& Hamidah, 2020).

Berdasarkan uraian tersebut maka identifikasi makroinvertebrata permukiman dipandang penting untuk dilakukan, sehingga dapat diketahui jenis hewan yang terdapat pada satu area permukiman dengan permukiman lain yang berbeda secara fisik. Hasil identifikasi tersebut juga dapat digunakan untuk memberikan gambaran tentang proses pengamatan langsung makroinvertebrata di permukiman yang dapat mendukung proses pembelajaran daring di tengah pandemi Covid-19. 


\section{METODE PENELITIAN}

Penelitian ini dilakukan pada bulan Agustus sampai September tahun 2020 di Kabupaten Bone, Sulawesi Selatan yang menjadi domisili beberapa orang mahasiswa Biologi FST UIN Alauddin Makassar. Dipilih lima lokasi pengamatan dengan kondisi fisik berbeda di lima dusun, yaitu lahan milik H. Alimuddin di Abbolange, H. Tahir di Bilae, H. Amir di Cempa-cempae, Haeruddin di Gattareng, dan Syamsul Bahri di Kampung Baru. Identifikasi makroinvertebrata dilakukan secara langsung di lokasi dengan pedoman identifikasi lapangan. Jenis yang tidak teridentifikasi langsung di lapangan dikoleksi dan dikirimkan ke Laboratorium Biologi, FST UIN Alauddin Makassar untuk identifikasi lebih lanjut.

Lokasi pengambilan sampel makroinvertebrata permukiman ditentukan pada lima titik lahan yang dimiliki warga. Kemudian menentukan titik tengah dari quadrant transect yang akan dibuat. Quadrant transect berukuran $50 \mathrm{~m}$ x $50 \mathrm{~m}$ (Rahman et al., 2019) berpusat pada pertengahan lahan tersebut, dengan $25 \mathrm{~m}$ masing-masing ke setiap arah mata angin (utara, timur, selatan, dan barat). Semua jenis makroinvertebrata yang berada dalam area tersebut kemudian ditangkap sebagai sampel untuk diidentifikasi. Pengambilan sampel makroinvertebrata permukiman dengan metode pengambilan secara langsung dengan tangan (hand-shorting) untuk hewan dengan mobilitas rendah. Sedangkan untuk hewan dengan mobilitas tinggi, ditangkap dengan menggunakan metode jaring ayun (sweep net). Hewan yang tertangkap kemudian dimatikan dalam larutan deterjen/dengan menggunakan kloroform pada killing jar. Koleksi makroinvertebrata permukiman diawetkan dengan formalin $4 \%$ di dalam botol sampel. Pengambilan sampel dilakukan setiap hari dalam kurun waktu satu minggu (7 hari). Pengukuran beberapa variabel faktor lingkungan dilakukan pada masing-masing titik sampling makroinvertebrata permukiman, meliputi: suhu, intensitas cahaya, dan kelembaban, dilakukan dua kali sehari yakni antara pukul 07:00 s.d. 09:00 pagi dan antara pukul 15:00 s.d. 17:00 sore yang menjadi puncak aktivitas sebagian besar hewan mikroinvertebrata.

Posttest, untuk mengukur dan mengetahui respon mahasiswa terhadap penggunaan metode pengamatan langsung makroinvertebrata di permukiman, dilakukan setelah semua rangkaian pengamatan di lapangan terselesaikan. Respon mahasiswa diketahui melalui pengisian formulir elektronik (Google Form). Selanjutnya data yang 
diperoleh dianalisis secara deskriptif dan dilaporkan dalam bentuk tabel dan gambar. Sampel dianalisis dengan menghitung banyaknya jenis dan jumlah makroinvertebrata yang tertangkap pada wilayah pengambilan sampel kemudian dihitung dengan menggunakan rumus Indeks keanekaragaman ( $\left.\mathrm{H}^{\prime}\right)$ dengan rumus Shannon-Wiener, indeks keseragaman (E) rumus Evenness-Index, dan indeks dominansi (D) dengan rumus Dominance of Simpson.

\section{HASIL DAN PEMBAHASAN}

1. Pengukuran Faktor Lingkungan

Faktor lingkungan yang diukur pada penelitian ini adalah temperatur, intensitas cahaya, dan kelembaban. Hasil pengukuran faktor lingkungan tersebut pada setiap lokasi penelitian ditunjukkan pada tabel 1 .

Tabel 1. Kondisi Fisik Lingkungan di Lima Titik Pengambilan Sampel

\begin{tabular}{ccccc}
\hline No. & Lokasi & $\begin{array}{r}\text { Temperatur } \\
\mathbf{(} \mathbf{C})\end{array}$ & $\begin{array}{c}\text { Intensitas Cahaya } \\
(\mathbf{l u x})\end{array}$ & $\begin{array}{c}\text { Kelembaban } \\
(\boldsymbol{\%})\end{array}$ \\
\hline 1 & ABB & 27,6 & 1074,4 & 59 \\
2 & BLA & 26,8 & 797,5 & 68 \\
3 & CMP & 28,4 & 1115,9 & 56 \\
4 & GTR & 27,1 & 973,6 & 64 \\
5 & KPB & 28,8 & 1249,0 & 49 \\
\hline
\end{tabular}

Keterangan: $\mathrm{ABB}=$ AbbolangE; $\mathrm{BLA}=$ BilaE; $\mathrm{CMP}=$ Cempa-cempa E; GTR $=$ Gattareng; $\mathrm{KPB}=$ Kampung Baru

Berdasarkan tabel 1, terlihat bahwa kondisi fisik lingkungan di lima lokasi pengambilan sampel berbeda-beda, karena komponen penyusun habitatnya juga berbeda-beda mulai dari jenis-jenis tumbuhan pakan, tipe vegetasi, sumber air, dan juga tutupan kanopi. Temperatur tertinggi pada lokasi ke-5, yakni di Kampung Baru (KPB) menunjukkan angka $28,8{ }^{\circ} \mathrm{C}$, dan terendah pada lokasi ke-2, Bilae (BLA) dengan temperatur $26,8{ }^{\circ} \mathrm{C}$. Intensitas cahaya tertinggi juga didapatkan di Kampung Baru sebesar 1249 lux dan terendah di Bilae dengan intensitas cahaya sebesar 797,5 lux. Sedangkan untuk parameter kelembaban, Bilae memiliki kelembaban tertinggi sebesar $68 \%$ dan terendah di Kampung Baru dengan nilai kelembaban 49\%. Kesehatan lingkungan permukiman meliputi kondisi fisik, kimia, dan biologi di lingkungan permukiman tersebut, sehingga masyarakat sekitar mencapai derajat kesehatan yang 
optimal (Keman, 2005). Kondisi fisik lingkungan ini sangat penting karena terkait dengan kebutuhan habitat dari faktor lainnya, yaitu faktor biologi yang salah satunya terdiri dari makroinvertebrata. Bahkan Husamah \& Rahardjanto (2019) menganggap bahwa indikator biologi (bioindikator) lebih dapat dipercaya daripada indikator lainnya, terutama indikator kimia.

2. Makroinvertebrata Permukiman

Jenis makroinvertebrata yang teridentifikasi pada pengamatan makroinvertebrata permukiman dapat dilihat pada tabel 2.

Tabel 2. Hasil Identifikasi Makroinvertebrata Permukiman

\begin{tabular}{|c|c|c|c|c|c|c|c|c|}
\hline \multirow{2}{*}{ No } & \multirow{2}{*}{ Jenis } & \multirow{2}{*}{ Ordo } & \multicolumn{5}{|c|}{ Lokasi } & \multirow{2}{*}{$\mathrm{n}$} \\
\hline & & & $\mathrm{ABB}$ & BLA & CMP & GTR & KPB & \\
\hline 1 & L. terrestris & Haplotaxida & 8 & 4 & 8 & 3 & 3 & 26 \\
\hline 2 & Philodromus sp. & Araneae & 8 & 7 & 8 & 6 & 6 & 35 \\
\hline 3 & Spirobolus sp. & Spirobolida & 3 & 2 & 2 & 1 & 0 & 8 \\
\hline 4 & Periplaneta sp. & Blattodea & 6 & 2 & 6 & 4 & 3 & 21 \\
\hline 5 & A. rufipes & Coleoptera & 3 & 0 & 3 & 2 & 2 & 10 \\
\hline 6 & Culex sp. & Diptera & 4 & 8 & 7 & 12 & 6 & 37 \\
\hline 7 & M. domestica & Diptera & 11 & 15 & 3 & 19 & 7 & 55 \\
\hline 8 & D. manifera & Homoptera & 1 & 0 & 0 & 0 & 0 & 1 \\
\hline 9 & L. acuta & Hemiptera & 1 & 0 & 0 & 0 & 0 & 1 \\
\hline 10 & $P$. prasine & Hemiptera & 0 & 1 & 0 & 0 & 0 & 1 \\
\hline 11 & A. cerrana & Hymenoptera & 4 & 1 & 4 & 0 & 1 & 10 \\
\hline 12 & Monomorium sp. & Hymenoptera & 17 & 23 & 22 & 5 & 13 & 80 \\
\hline 13 & $V$. squamosa & Hymenoptera & 1 & 1 & 0 & 0 & 0 & 2 \\
\hline 14 & Coptotermes sp. & Isoptera & 16 & 0 & 0 & 0 & 0 & 16 \\
\hline 15 & C. sphinx & Lepidoptera & 1 & 1 & 2 & 1 & 1 & 6 \\
\hline 16 & I. juventa & Lepidoptera & 2 & 2 & 5 & 2 & 3 & 14 \\
\hline 17 & H. vitrea & Mantodea & 1 & 0 & 0 & 1 & 1 & 3 \\
\hline 18 & M. formicarius & Neuroptera & 0 & 0 & 9 & 0 & 0 & 9 \\
\hline 19 & O. sabina & Odonata & 7 & 7 & 8 & 9 & 10 & 41 \\
\hline 20 & Gryllus sp. & Orthoptera & 1 & 1 & 0 & 0 & 0 & 2 \\
\hline 21 & V. nigricornis & Orthoptera & 8 & 6 & 8 & 8 & 6 & 36 \\
\hline 22 & P. humanus & Phthiraptera & 0 & 0 & 2 & 0 & 0 & 2 \\
\hline 23 & A. fulica & Achatinoidea & 7 & 7 & 10 & 6 & 5 & 35 \\
\hline \multicolumn{3}{|c|}{$\mathbf{N}$} & 110 & 88 & 107 & 79 & 67 & 451 \\
\hline
\end{tabular}


Berdasarkan tabel 2, terlihat bahwa terdapat total (N) 451 ekor makroinvertebrata yang ditemukan pada penelitian ini. Tersebar ke dalam lima lokasi pengambilan sampel, dengan lokasi Abbolange (ABB) memiliki jumlah paling melimpah (110 ekor) dan Kampung Baru (KPB) dengan jumlah paling sedikit (67). Semut jenis Monomorium sp. menjadi jenis hewan dengan jumlah (n) terbanyak yaitu sebanyak 80 ekor, sedangkan D. manifera (Homoptera), L. acuta, dan P. prasina (Hemiptera) dengan jumlah masing-masing 1 ekor menjadi yang paling sedikit.

Distribusi makroinvertebrata berdasarkan filum (Gambar 1) menunjukkan Filum Arthropoda dengan persentase sebesar 86\% (390 ekor) mendominasi dua filum lainnya, yaitu Mollusca 8\% (35 ekor), dan Annelida 6\% (26 ekor). Jika diturunkan ke kategori kelas: Oligochaeta, Arachnida, Diplopoda, Insecta, dan Gastropoda (Gambar 2), maka Kelas Insecta menjadi yang terbanyak dengan persentase 77\% (347 ekor) dan yang tersedikit yaitu Kelas Diplopoda ( $2 \%=8$ ekor). Sedangkan jika diturunkan lagi pada kategori ordo (Gambar 3), maka Ordo Hymenoptera dan Diptera menjadi yang paling besar jumlahnya dengan persentase 20\% (92 ekor), dan Ordo Homoptera dengan jumlah yang paling kecil, yakni <1\% (1 ekor). Terdapat total 16 ordo yang diamati dalam penelitian ini, yaitu: Haplotaxida, Araneae, Spirobolida, Blattodea, Coleoptera, Diptera, Hemiptera, Hymenoptera, Isoptera, Lepidoptera, Mantodea, Neuroptera, Odonata, Orthoptera, Phthiraptera, dan Achatinoidea. Dominansi Filum Arthropoda menjadi sebuah kewajaran, karena menurut Grimaldi \& Engel (2005), Arthropoda mencakup lebih dari setengah dari jumlah keseluruhan biota multiseluler yang ada di muka bumi.

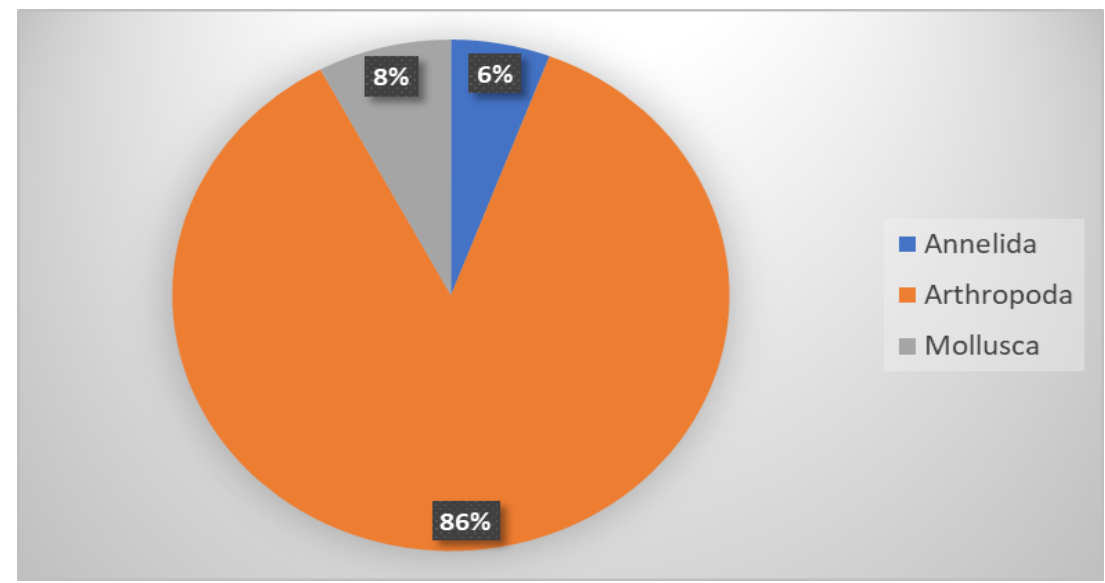

Gambar 1. Distribusi makroinvertebrata berdasarkan filum 


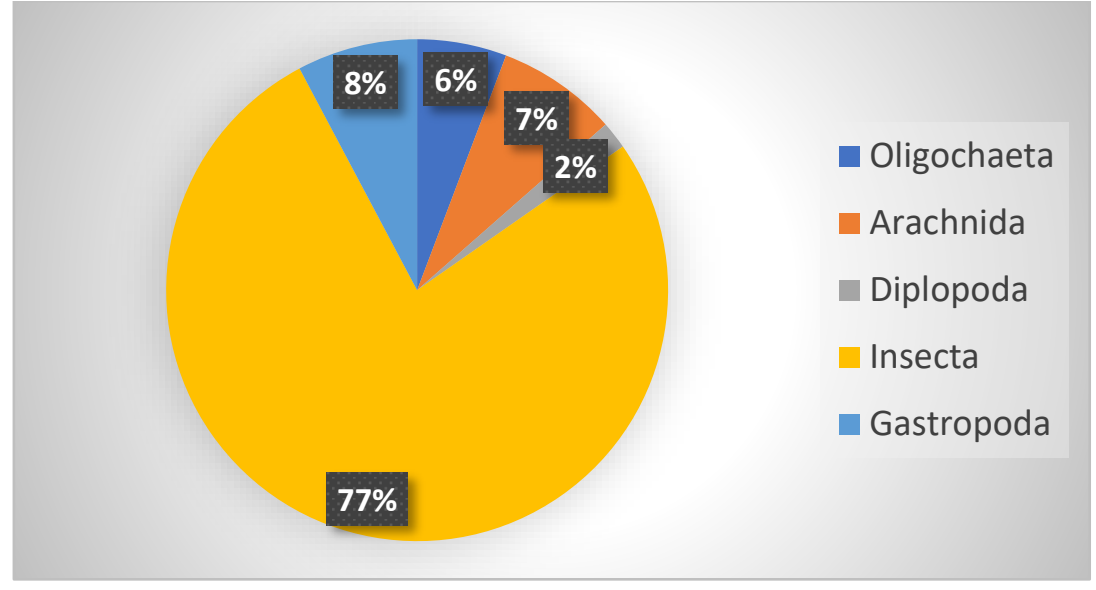

Gambar 2. Distribusi makroinvertebrata berdasarkan Kelas

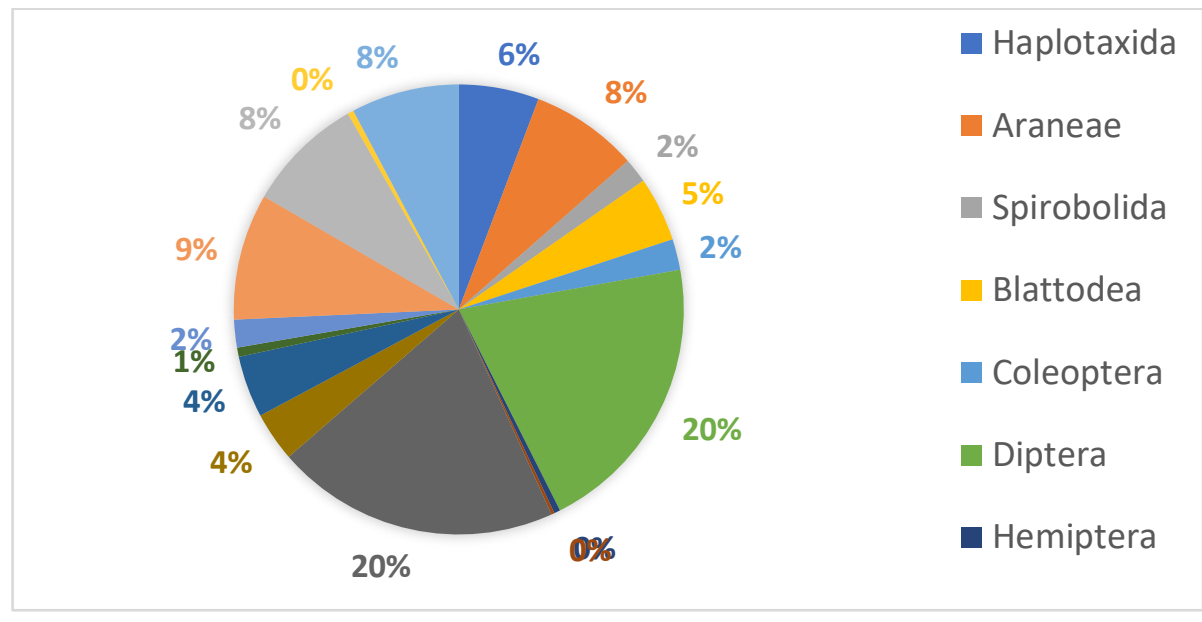

Gambar 3. Distribusi makroinvertebrata berdasarkan Ordo

Indeks ekologi yang dihitung meliputi Indeks Keanekaragaman Jenis (H'), Indeks Keseragaman (E) dan Indeks Dominansi (D). Hasil analisis data menunjukkan nilai H' $=2,64$. Angka ini menunjukkan bahwa keanekaragaman jenis makroinvertebrata pada penelitian ini termasuk dalam kategori sedang karena berada pada kisaran kriteria $1<$ H' $<3$ menurut (Wilhm \& Dorris, 1968). Nilai $\mathrm{E}=0,84$ berarti keseragaman populasi dalam komunitas berada pada skala tinggi, dengan kriteria $E>0,6$. Sedangkan untuk nilai $\mathrm{D}=0,09$. Nilai tersebut lebih mendekati 0 daripada mendekati 1 , artinya secara umum tidak terjadi dominansi dalam komunitas makroinvertebrata di lima lokasi penelitian.

Parameter fisik lingkungan ini disebut juga parameter ekologi, karena menentukan interaksi antara organisme hewan dengan lingkungannya. Terutama pada habitat 
terrestrial di penelitian kali ini. Faktor temperatur terkait dengan kondisi ekstrim yang berkaitan dengan energi yang juga berdampak pada keseimbangan air dalam tubuh. Lingkungan terestrial juga biasanya berkaitan dengan ketersediaan kelembaban. Berdasarkan kelembaban, habitat terrestrial terbagi menjadi lingkungan xeric yang kering, lingkungan mesic yang memiliki jumlah air sedang, dan habitat hydric yang sangat basah (Brusca et al., 2016).

Parameter instensitas cahaya juga merupakan faktor atau stimulus lingkungan yang paling berpengaruh. Biasanya suatu organisme merespon dengan bergerak mendekat atau menjauhi sumber cahaya. Kehidupan dan lingkungan tidak bisa dipisahkan. Mempelajari sejarah evolusi dari suatu garis keturunan populasi dapat dipelajari dari lingkungan tempat terjadinya kehidupan tersebut (Hickman et al., 2017).

Terdapat tiga filum, lima kelas, dan 17 ordo yang ditemukan dalam penelitian makroinvertebrata permukiman kali ini. Sesuai dengan pernyataan Brusca et al., (2016) bahwa jumlah filum hewan yang hidup di habitat terrestrial relatif sedikit dibanding habitat akuatik. Keberhasilan invertebrata di darat dicontohkan oleh Arthropoda, terutama Isopoda darat, serangga, laba-laba, tungau, kalajengking, dan Arachnida lainnya. Kelompok Arthropoda ini termasuk spesies yang benar-benar terrestrial yang telah menginvasi lingkungan yang paling kering sekalipun. Kecuali beberapa siput dan Nematoda, semua invertebrata penghuni darat lainnya, termasuk hewan yang dikenal seperti cacing tanah, sebagian besar terbatas pada daerah yang relatif lembab.

Perubahan morfologi dan fungsi sebagai bentuk adaptasi memungkinkan hewan untuk hidup di habitat yang berbeda. Invertebrata menempati berbagai macam habitat dan telah menyesuaikan diri dengan cara hidup yang berbeda. Mereka ditemukan di laut, di air tawar, di udara, dan di semua bagian daratan dari pegunungan yang tertutup salju hingga gurun. Annelida dapat hidup di habitat berupa tanah yang lembab, berbeda dengan filum-filum di bawahnya (Porifera, Coelenterata, Platyhelminthes dan Nematoda) dan beberapa memiliki kebiasaan yang sanguivorous atau menghisap darah seperti lintah. Invertebrata yang paling beragam dan berhasil secara biologis di antara semua hewan adalah Arthropoda. Filum ini dapat hidup di semua jenis habitat dan mengkonsumsi makanan dalam jumlah dan variasi terbesar, yang mana serangga adalah satu-satunya invertebrata yang mampu terbang. Moluska sebagian besar hidup di laut, 
tetapi siput dan kerang hidup di air tawar, sementara beberapa spesies siput dan keong atau bekicot hidup di darat (Kotpal, 2013).

Hasil dan interpretasi dari indeks-indeks ekologi ini berkaitan dengan peran makroinvertebrata sebagai bioindikator kualitas lingkungan, karena dapat menunjukkan adanya perubahan habitat dan pencemaran lingkungan. Makroinvertebrata dapat dijadikan sebagai bioindikator, karena efektivitasnya dalam melakukan biomonitoring (Widiyanto \& Sulistyarsi, 2016). Umumnya yang banyak digunakan sebagai bioindikator adalah serangga (Taradipha \& Rushayati, 2019). Walaupun faktanya jenisjenis hewan yang ditemukan pada penelitian ini ada yang bertindak sebagai scavenger (L. terrestris dan A. rufipes), predator (Philodromus sp., O. sabina, H. vitrea, dan M. formicarius), hama (Ordo Hemiptera, Isoptera, Orthoptera, dan Achatinoidea), pollinator (Ordo Lepidoptera dan Hymenoptera), vektor penyakit (Ordo Diptera), juga ada yang bertindak sebagai parasit yaitu jenis kutu rambut $P$. humanus. Makroinvertebrata yang ditemukan secara garis besar dikategorikan menguntungkan dan merugikan. Jenis-jenis yang merugikan (karena bertindak sebagai hama, parasit, dan vektor penyakit), seperti nyamuk, lalat, kecoa, semut, dan laba-laba, hidup berdampingan dengan manusia di area permukiman. Namun keberadaanya sering kali tidak diinginkan karena memiliki reputasi yang buruk bagi para pemukim, seperti indikator lingkungan kumuh, serta menyebarkan penyakit dan allergen (Hadi, 2012)

Hasil identifikasi jenis hewan makroinvertebrata beserta dengan indeks ekologi serta peranananya di lingkungan permukiman ini dapat menjadi tambahan pembelajaran bagi mahasiswa. Apalagi dalam kondisi yang masih terbatasi oleh wabah Covid-19 seperti sekarang ini. Mahasiswa biologi khususnya, lebih memilih pembelajaran bersifat visual (Maulah \& Ummah, 2020), yang mana pengamatan langsung di permukiman dapat menjadi salah satu opsi metode yang efektif. Proses identifikasi pun dapat dilakukan secara sederhana dengan memperhatikan ciri morfologi dengan Field Identification Guide yang difasilitasi ataupun diarahkan oleh dosen, laboran, ataupun asisten yang bertanggung jawab dalam Praktikum Taksonomi Invertebrata. Selain dapat memberikan pengalaman belajar mandiri dengan mengeksplorasi lingkungan sekitar permukimannya, juga memberikan suasana belajar baru yang tidak harus selalu di depan layar komputer/telepon pintar masing-masing. Sedikit kendala yang harus dihadapi adalah keterbatasan alat untuk pengukuran parameter fisik lingkungan yang tidak 
dimiliki oleh setiap mahasiswa. Begitupun dengan perangkat pembuatan awetan spesimen, baik awetan kering maupun awetan basah.

3. Tingkat pemahaman mahasiswa

Tingkat pemahaman mahasiswa dalam pelaksanaan mata kuliah Praktikum Taksonomi Invertebrata ini melihat beberapa paramater, yaitu perubahan pemahaman sebelum dan setelah melaksanakan praktikum dari rumah, urgensi praktikum lapangan, dan ketercapaian informasi/pemahaman dengan metode pelaksanaan praktikum dari rumah. Gambar 4 menunjukkan persentase ketercapaian tingkat pemahaman mahasiswa sebelum dan setelah melakukan pengamatan secara langsung terkait jenis-jenis makroinvertebrata yang ada di sekitar rumah masing-masing, terlihat bahwa 57\% dari responden yang mengalami peningkatan pemahaman, hal ini menegaskan bahwa pengamatan langsung memberikan dampak yang sangat significan dalam menstimulus pemahaman mahasiswa. Meskipun juga tidak dapat diingkari bahwa yang tidak meningkat (tetap) juga memiliki persentase yang cukup tinggi yaitu $43 \%$. Begitu juga tingkat ketercapaian pemahaman mahasiswa pada gambar 5 terlihat bahwa persentase jumlah responden yang memilih bahwa pengamatan langsung di rumah belum mampu mengakomodir seluruh pemahaman mahasiswa terkait makroinvertebarata. Sehingga hal ini sangat relevan dengan gambar 6 yang memperlihatkan bahwa pelaksanaan praktikum lapangan secara bersama pada lokasi tertentu yang diperkirakan memiliki jenis-jenis yang lebih representatif. Sebagaimana yang telah diketahui bahwa biologi merupakan salah satu program studi yang memiliki banyak praktikum baik di laboratorium, maupun di lapangan untuk menunjang pengetahuan peserta didik secara langsung (Sutopo, 2015). Inovasi metode pembelajaran sangat penting untuk dilakukan, agar dapat menghindari kejenuhan mahasiswa. Kejenuhan terjadi jika metode model pembelajaran dilakukan secara monoton (Pawicara \& Conilie, 2020). 


\section{Tingkat Pemahaman}

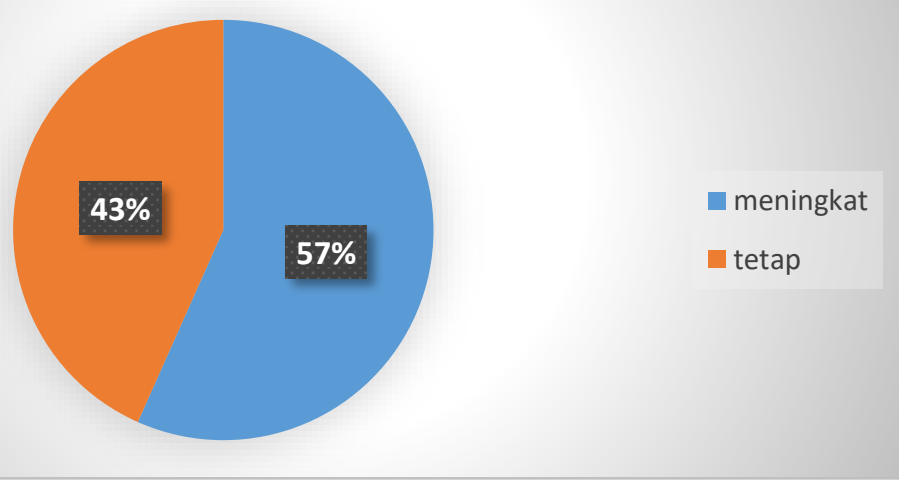

Gambar 4. Tingkat pemahaman mahasiswa setelah pengamatan lapangan

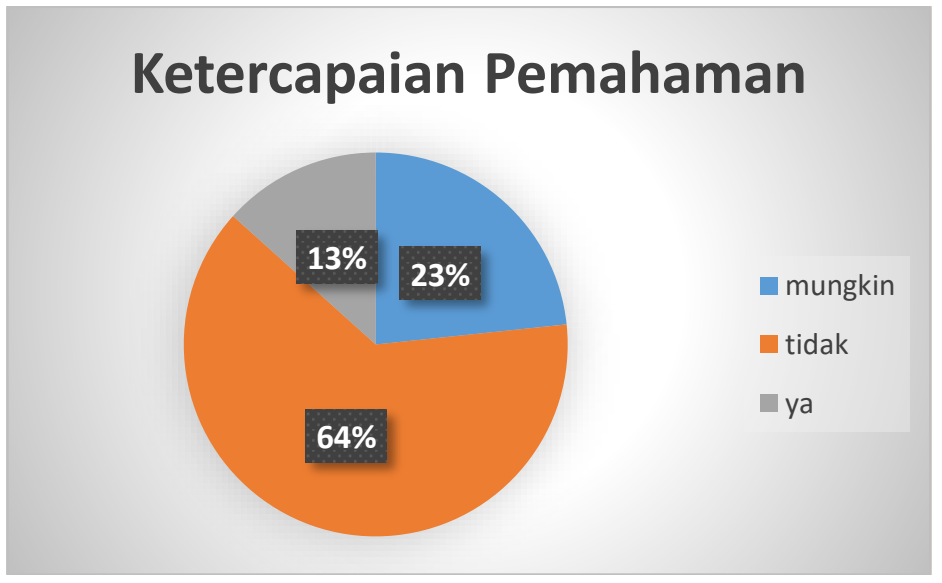

Gambar 5. Tingkat ketercapaian pemahaman mahasiswa dengan praktikum dari rumah

\section{Urgensi Praktikum}

\section{Lapangan}

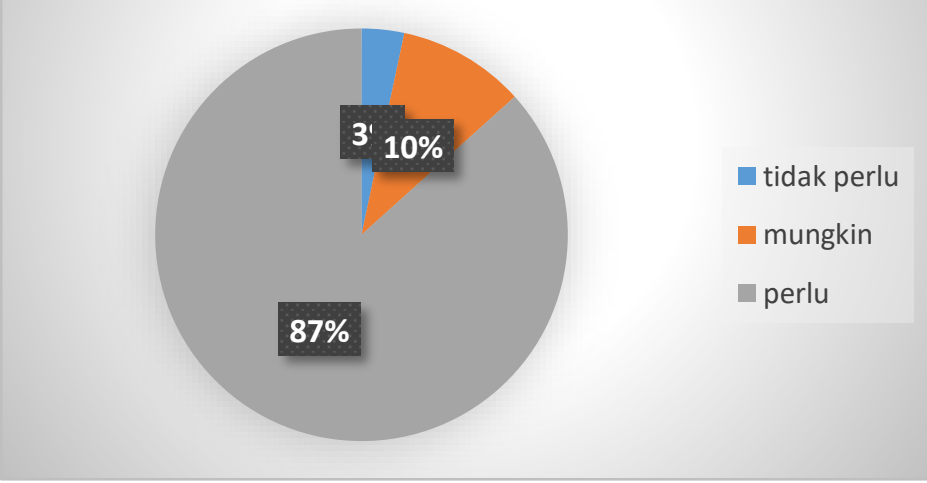

Gambar 6. Urgensi pelaksanaan praktikum lapangan 


\section{SIMPULAN}

Ditemukan 23 jenis makroinvertebrata di lima titik pengamatan pada lahan warga sekitar permukiman di Kabupaten Bone. Jenis-jenis hewan tersebut dikelompokkan ke dalam 17 ordo, 5 kelas, dan 3 filum. Hewan makroinvertebrata yang teridentifikasi memiliki berbagai peranan mulai dari scavenger, predator, hama, pollinator, vektor penyakit, dan juga sebagai parasit. Namun secara keseluruhan berperan sebagai bioindikator melalui penghitungan indeks ekologi. Nilai $\mathrm{H}^{\prime}=2,64$; nilai $\mathrm{E}=0,84$; dan nilai $\mathrm{D}=0,09$ menunjukkan kondisi stabilitas lingkungan dalam kategori baik, karena memiliki keanekaragaman sedang, keseragaman yang tinggi, dan tidak terjadi dominansi dalam komunitas di habitat yang menjadi lokasi penelitian.

Hewan-hewan yang teridentifikasi dapat menjadi media belajar langsung bagi mahasiswa dengan metode eksplorasi mandiri yang dapat meningkatkan aktivitas meskipun di lingkungan yang terbatas oleh wabah Covid-19. Hal ini ditunjukkan dari 57\% mahasiswa yang mengalami peningkatan pemahaman dengan adanya kegiatan pengamatan langsung makroinvertebrata permukiman. Namun demikian, kegiatan tersebut belum dirasa cukup untuk mengakomodir pemahaman mahasiswa secara keseluruhan, dengan $64 \%$ mahasiswa masih merasa belum cukup memahami tentang invertebrata, sehingga pelaksanaan praktikum lapangan masih dipandang perlu untuk dilakukan dengan persentase $87 \%$.

\section{DAFTAR PUSTAKA}

Amrullah, S. H. (2018). Indeks Keanekaragaman Capung (Insecta: Odonata) sebagai Pengukur Kualitas Lingkungan Sungai dalam Kawasan Taman. Nasional Bantimurung Bulusaraung. Seminar Nasional Hasil Penelitian \& Pengabdian, 2018, 86. http://jurnal.poliupg.ac.id/index.php/snp2m/article/download/825/719

Brusca, R. C., Moore, W., \& Shuster, S. M. (2016). Invertebrates. Third Edition . Invertebrates., 193-196, 347. https://doi.org/10.1086/694987

Grimaldi, D., \& Engel, M. S. (2005). Evolution of The Insects. Cambridge University Press.

Hadi, U. K. (2012). Serangga Pengganggu Kesehatan (Nyamuk, Lalat, Kecoa, Semut, Labah-labah). http://upikke.staff.ipb.ac.id/files/2012/11/Serangga-PenggangguKesehatan-Nyamuk-Lalat-Lipas-Semut-Labah-Labah-nov-2012.pdf

Hanafiah, K. A., Napoleon, A., \& Ghofar, N. (2013). Biologi Tanah: Ekologi dan Makrobiologi Tanah. PT. Raja Grafindo Persada.

Hickman, C. P., Keen, S., Eisenhour, D., Larson, A., \& Anson, H. (2017). Integrated Principles of Zoology (17th ed.). McGraw-Hill Education.

Husamah, \& Rahardjanto, A. (2019). (Teori dan Aplikasi dalam Biomonitoring). Penerbit Universitas Muhammadiyah Malang. http://ummpress.umm.ac.id 
Keman, S. (2005). Kesehatan Perumahan dan Lingkungan Pemukiman. Jurnal Kesehatan Lingkungan Unair, 3947. http://www.journal.unair.ac.id/filerPDF/KESLING-2-1-04.pdf

Komarawidjaja, W. (2011). Status Makro Invertebrata Pada Perairan DAS Citarum Hulu Yang Tercemar. In Jurnal Teknologi Lingkungan BPPT (Vol. 6, Issue 3, p. 149137). Agency for the Assessment and Application of Technology Indonesia. https://doi.org/10.29122/JTL.V6I3.351

Kotpal, R. (2013). Modern Textbook of Zoology Invertebrates I (10th ed.). Rastogi Publication.

Kristiani, M. K., Rondonuwu, D. M., \& Warouw, F. (2015). Analisis Kondisi Permukiman Kawasan Industri Perikanan Laut Kelurahan Aertembaga Satu Kota Bitung. Spasial, 1(1), 94-104. https://ejournal.unsrat.ac.id/index.php/spasial/article/view/9185

Maulah, S., \& Ummah, N. R. (2020). Persepsi Mahasiswa Biologi Terhadap Perkuliahan Daring Sebagai Sarana Pembelajaran Selama Pandemi Covid 19. Alveoli: Jurnal Pendidikan, 1(2), 49-61. https://alveoli.iainjember.ac.id/index.php/alv/article/view/6

Meilin, A., \& Nasamsir. (2016). Serangga dan Peranannya dalam Bidang Pertanian Dan $\begin{array}{llll}\text { Kehidupan. Jurnal Media } & \text { Pertanian, }\end{array}$ https://doi.org/10.33087/jagro.v1i1.12

Pawicara, R., \& Conilie, M. (2020). Analisis Pembelajaran Daring Terhadap Kejenuhan Belajar Mahasiswa Tadris Biologi Iain Jember di Tengah Pandemi Covid-19. Alveoli: Jurnal Pendidikan Biologi, 1(1), 29-38. https://alveoli.iainjember.ac.id/index.php/alv/article/view/7

Rahman, I., Waspodo, S., Damayanti, A. A., Himawan, M. R., \& Gigentika, S. (2019). Penyuluhan Mengenai Jenis, Manfaat, Status dan Ancaman Ekosistem Lamun di Perairan Pantai Sire, Kabupaten Lombok Utara. Seminar Nasional Pengabdian Kepada Masyarakat LPPM Universitas Mataram, 1(1), 262-266. http://jurnal.lppm.unram.ac.id/index.php/prosidingpepadu/article/view/42

Sadikin, A., \& Hamidah, A. (2020). Pembelajaran Daring di Tengah Wabah Covid-19. BIODIK: Jurnal Ilmiah Pendidikan Biologi, 6(2), 214-224. https://doi.org/10.22437/bio.v6i2.9759

Sutopo, A. H. (2015). Pengembangan Bahan Ajar Berbasis Multimedia. Tersedia: Http://Www. Topazart. Mat/Flash/TutorialBahanAjarMultimedia. Pdf, 22-29. Info/Teks_teaching

Widiyanto, J., \& Sulistyarsi, A. (2016). Biomonitoring Kualitas Air Sungai Madiun dengan Bioindikator Makroinvertebrata 1) 2). Jurnal Penelitian LPPM (Lembaga Penelitian Dan Pengabdian Kepada Masyarakat) IKIP PGRI MADIUN, 4(1), 1-9. http://e-journal.unipma.ac.id/index.php/JP-LPPM/article/view/395

Wilhm, J. L., \& Dorris, T. C. (1968). Biological Parameters for Water Quality Criteria. BioScience, 18(6), 477-481. https://doi.org/10.2307/1294272 